\title{
Studi Korelasi antara Teacher Learning Climate dengan Job Satisfaction pada Guru Sekolah Menengah Pertama (SMP) Kota Bandung
}

\section{Correlation Study between Teacher Learning Climate with Job Satisfaction Towards Public Middle Schools Teacher in Bandung City}

\author{
Sekar Ayu Anjani ${ }^{1}$, Anissa Lestari Kadiyono ${ }^{2}$ \\ ${ }^{1,2}$ Fakultas Psikologi, Universitas Padjadjaran, \\ Jl. Raya Bandung Sumedang KM.21, Hegarmanah, Jatinangor \\ Kabupaten Sumedang, Jawa Barat 45363 \\ Email:ayu.anjanisekar@gmail.com; anissa.lestari@unpad.ac.id
}

\section{KATA KUNCI KEYWORDS}

ABSTRAK
Teacher learning climate, job satisfaction, guru, SMPN Kota Bandung Teacher learning climate, job satisfaction, teacher, public middle school

Sekolah sebagai tempat terselenggaranya pendidikan sebaiknya memberikan ruang pembelajaran bagi guru selaku pendidik agar mampu menyesuaikan kemampuan dan wawasannya pada sistem penyelenggaraan pendidikan yang terus berubah. Hal ini dikenal dengan nama iklim belajar guru. Dengan adanya iklim belajar guru maka diharapkan kepuasan kerja sebagai guru pun meningkat. Tujuan penelitian ini adalah memberi gambaran mengenai hubungan antara teacher learning climate dan job satisfaction pada guru SMP Negeri Kota Bandung. Penelitian ini dilakukan terhadap 109 guru yang aktif mengajar di SMP Negeri Kota Bandung. Rancangan penelitian yang digunakan adalah non-eksperimental kuantitatif dengan metode korelasi. Pengambilan data dilakukan menggunakan kuesioner dengan pemilihan sampel cluster random sampling. Hasil penelitian menunjukkan bahwa terdapat hubungan yang signifikan antara teacher learning climate dengan job satisfaction pada guru SMP Negeri Kota Bandung. Namun, diketahui dalam penelitian ini bahwa kepuasan guru SMP Negeri Kota Bandung pada dimensi advancement masuk dalam kategori rendah dan tidak memiliki hubungan dengan teacher learning climate. Artinya, kepuasan kerja guru SMP Negeri Kota Bandung terhadap kesempatan mendapatkan promosi harus ditingkatkan.

School as the place where education took place must give a big learning chance for teachers so they could adjust easily their ability and insights to the education operational system that keep changes, which is by applying teacher's learning climate. A big teacher's learning chances will increase teacher's work satisfaction. Objective of this study is to give description about relationship between teacher learning climate and job satisfaction towards public middle school's teacher in Bandung City. A nonexperimental quantitative research design with correlation method conducted to 109 teachers that is currently active in public middle schools in Bandung. Data collection was taken using questionnaire with sample selection cluster random sampling. The result of this study showed that there is a significant relation between teacher learning climates with job satisfaction in public middle school teachers in Kota Bandung. In addition, this study was found that the satisfaction of public middle school teachers in Bandung City in advancement dimension fell into the low category and there was no relation with teacher learning climate. This means, the work satisfaction of public middle school teachers in Bandung City toward the chance to gain promotion needs to be improved. 


\section{PENDAHULUAN}

Sekolah
menyelenggarakan $\quad \begin{array}{r}\text { tempat } \\ \text { pendidikan }\end{array}$ membutuhkan peran seorang guru sebagai sumber daya utama berjalannya pendidikan tersebut. Menurut Pasal 1 UU No. 14 Tahun 2005 Tentang Guru dan Dosen, guru adalah pendidik profesional dengan tugas utama mendidik, mengajar, membimbing, mengarahkan, melatih, menilai, dan mengevaluasi peserta didik pada pendidikan anak usia dini jalur pendidikan formal, pendidikan dasar, dan pendidikan menengah (2013). Menurut Jyoti dan Sharma (dalam (Ayele, 2014), disamping tugas utama tersebut, peran guru juga sebagai role model karena mereka merupakan pilar yang membantu siswa tidak hanya untuk tumbuh tetapi juga menjadi calon pemimpin generasi berikutnya, dan untuk memikul tanggung jawab membawa bangsa mereka maju ke depan. Hal ini menunjukkan bahwa tanggung jawab guru cukup berat. Peran mereka sangat dibutuhkan untuk menghasilkan calon-calon penerus bangsa yang cerdas dan siap menghadapi persaingan global.

Perubahan-perubahan pada sistem pendidikan dan kemajuan teknologi serta informasi menyebabkan guru memiliki tantangan tersendiri yang harus dihadapi. Seperti perkembangan teknologi yang menyebabkan peran guru dan sekolah sebagai pusat pembelajaran mulai bergeser. Pergeseran tersebut bermaksud sebagaimana pada zaman ini guru memiliki tugas-tugas lain, selain kewajibannya sebagai fasilitator, yaitu juga menjadi panutan bagi siswanya. Selain itu juga pendidik sebagai abdi negara dituntut juga harus mampu menjadi abdi yang baik bagi negara, segala aturan dan tuntutan dari pemerintah hendaknya mampu terakomodir dengan baik oleh setiap pendidik (Aziz Shofi Nurdiansyah, 2011). Dengan demikian, guru harus dapat memanfaatkan segala hal yang ada disekitarnya, termasuk teknologi untuk terlibat pada proses pengajaran pada siswa. Tentu hal ini membutuhkan dukungan dan fasilitas dari sekolah dan penyelenggara pendidikan terkait agar mempermudah belajar guru. Apabila guru dapat merasakan adanya dukungan sosial dari lingkungannya, terutama dari kepala sekolahnya, hal tersebut akan memperlihatkan angka kepuasan kerja yang lebih tinggi yang mana tingginya tingkat kepuasan kerja tersebut dapat menunjukkan tingkat loyalitas yang lebih tinggi guru pada sekolahnya (Mooradian, Renzl, \& Matzler, 2006). Dalam hal ini berarti kepuasan kerja guru di sekolah juga menjadi penting karena berdampak bagi guru dan sekolah.

Teacher learning climate (TLC) atau iklim belajar guru merupakan suatu iklim belajar yang mengacu pada berbagai norma pembelajaran dan kegiatan dimana guru berusaha untuk memperluas kemampuan mereka dengan maksud menciptakan hasil pedagogis yang berharga dan mendorong adanya suatu pola pikir baru. Hal tersebut menurut Mikkelsen dan Gronhaug dalam (Shoshani \& Eldor, 2016). Hasil pedagogis yang dimaksud adalah seni cara mengajar guru yang menggunakan berbagai keterampilan dan kemampuannya dalam menyampaikan ilmu kepada siswa. Sedangkan pola pikir yang baru adalah sebagai cara agar guru dapat memanfaatkan teknologi informasi untuk memecahkan tantangan-tantangan masa depan yang mendesak (Aziz Shofi Nurdiansyah, 2011). Apabila diterjemahkan ke dalam sistem pendidikan, teacher learning climate merupakan upaya sekolah untuk mengubah belajar menjadi bagian integral dari bekerja dan memberikan kesempatan untuk belajar dan pertumbuhan berkelanjutan, menurut Marsick, Watkins, Callahan, Volpe (dalam (Erdem, İlğan, \& Uçar, 2014). Teacher learning climate mencerminkan persepsi guru tentang sejauh mana upaya sekolah mendorong pembelajaran dan memberikan kesempatan untuk pembelajaran, penyelidikan dan dialog terus menerus, pembelajaran dan timbal balik dalam tim, pemberdayaan menuju kolektif, visi, dan pembelajaran kepemimpinan (Munters, 
2009). Mengacu pada hal tersebut, Atkinson dan Hilgard (dalam (Renkl \& Atkinson, 2007) mendefinisikan persepsi sebagai pemaknaan informasi sensoris yang diterima secara keseluruhan menjadi model nyata yang menjadi pertimbangan dalam membuat keputusan dan melakukan tindakan. Menurut (Yang, Watkins, \& Marsick, 2004), aspek-aspek yang membentuk persepsi terhadap upaya sekolah mendukung pembelajaran guru adalah memberi kesempatan untuk berkembang dan memperbanyak ilmu (create continuous learning), mendorong guru saling berbagi ilmu pengetahuan dan membuat wadah untuk berdiskusi (promote inquiry and dialogue), kolaborasi dan pembelajaran berkelompok (collaboration and team learning), membentuk sistem teknologi dan informasi untuk saling berbagi pembelajaran yang berintegrasi dengan pekerjaan sebagai guru (create systems to capture and share learning), memberdayakan guru (empower people), membuat program yang menghubungkan sekolah dan masyarakat (connect the organization with its environment), dan adanya kepemimpinan yang strategis (provide strategic leadership).

Persepsi yang telah dibangun oleh guru kemudian akan membentuk evaluasi positif atau negatif sesuai dengan pemaknaannya dalam diri mereka. Apabila iklim belajar yang telah dibangun oleh sekolah dapat membantu guru dalam mengadaptasikan diri mereka terhadap perubahan-perubahan lingkungannya, maka akan tercipta sikap positif, begitu juga sebaliknya. Sikap positif atau negatif tersebut kemudian akan mempengaruhi kepuasan kerja guru. Kepuasan kerja guru merupakan kombinasi dari kondisi psikologis dan fisiologis yang menyebabkan seseorang merasa senang ketika melakukan pekerjaannya (Lester, 1987). Angka yang tinggi dalam kepuasan kerja juga menjadi prediksi performansi kerja yang tinggi menurut Judge, Thoresen, Bono, dan Patton (dalam (Von der Embse dkk, 2016) Dalam hal ini, Thrustone (dalam
(Lester, 1987) mengidentifikasikan bahwa terdapat sembilan faktor yang mendukung kepuasan kerja guru, yaitu:

1. Supervision, yaitu kepuasan kerja guru yang diakibatkan oleh peran dan hadirnya kepala sekolah.

2. Colleagues, yaitu kepuasan kerja guru yang diakibatkan oleh hubungan yang dibangun dengan rekan kerja.

3. Working Conditions, yaitu kepuasan kerja guru yang diakibatkan oleh kondisi pekerjaan yang mengacu pada karakteristik lingkungan dari situasi mengajar.

4. Pay

Tinggi rendahnya kepuasan kerja guru yang diakibatkan oleh kesesuaian upah yang didapat sebagai timbal balik dari sekolah.

5. Responsibility, yaitu kepuasan kerja guru yang diakibatkan oleh rasa tanggung jawab sendiri untuk menyelesaikan pekerjaannya, membantu siswa untuk memahami atau mempelajari berbagai hal, dan taat terhadap peraturan-peraturan sekolah atau membuat keputusan untuk melaksanakan suatu kegiatan.

6. Work Itself, yaitu kepuasan kerja guru diakibatkan oleh penyelesaianpenyelesaian tugas harian, memunculkan kreatifitas, dan adanya kemandirian.

7. Advancement, yaitu kepuasan kerja guru yang diakibatkan oleh adanya kesempatan mendapatkan promosi.

8. Security, yaitu kepuasan kerja guru yang diakibatkan oleh perasaan aman dengan ia mengajar di sekolah tersebut sebagai organisasi, misalnya perasaan ketakutan akan kehilangan pekerjaan tersebut.

9. Recognition, yaitu kepuasan kerja guru yang diakibatkan oleh perolehan pujian, kritikan, celaan dari orang lain kepadanya.

Penelitian lain yang dilakukan oleh (Shoshani \& Eldor, 2016) pada 273 guru 
dan 1040 siswa di 23 sekolah dasar dan sekolah menengah di Israel menunjukkan bahwa teacher learning climate dan teacher job satisfaction memiliki hubungan yang signifikan sehingga kepuasan kerja pada guru juga dapat berdampak positif pada komitmen kerja, kesejahteraan, dan ikatan guru pada pekerjaannya tersebut. Selain itu, penelitian yang dilakukan oleh (Degree \& Background, 2012) menunjukkan bahwa semakin terbuka iklim belajar maka akan semakin tinggi juga kepuasan kerja individu.

Kota Bandung sebagai ibukota Jawa Barat merupakan salah satu kota dengan jumlah sekolah terbanyak di Indonesia. Selain itu, Bandung juga merupakan salah satu kota pendidikan di Indonesia dengan jumlah sekolah terakreditasi A terbanyak di Pulau Jawa-Bali (Pramesti, 2018). Dalam rangka terus mempertahankan pencapaian Bandung dalam bidang pendidikan tersebut, Pemerintah Kota Bandung merancangkan misi tingkatkan kualitas pendidikan Kota Bandung (Sosiawan, 2008), antara lain:

1. Menyelenggarakan pendidikan yang merata dan berkeadilan.

2. Mewujudkan pendidikan yang unggul dan bermutu.

3. Meningkatkan sarana dan prasarana pendidikan yang berwawasan lingkungan.

4. Meningkatkan profesionalisme serta mutu tenaga kependidikan.

5. Mengembangkan pendidikan karakter.

6. Penyelenggaran pendidikan yang dapat memenuhi kebutugan lapangan kerja.

Mengacu pada hal tersebut, Pemerintah Kota Bandung lebih memfokuskan enam misi tersebut lebih kepada siswa SMP karena adanya pergeseran kewenangan pengelolaan pendidikan tingkat SMA dan SMK yang pindah ke provinsi (Sosiawan, 2008). Dalam rangka mencapai misi tersebut, Pemerintah Kota Bandung melakukan berbagai macam upaya yang salah satunya adalah memperbaiki sistem pendidikan Kota Bandung. Perubahan sistem tersebut diterapkan mulai dari sistem penerimaan peserta didik baru (PPDB) hingga pelaksanaan kegiatan belajar-mengajar.

Pada tahun 2015 diketahui bahwa

Kota Bandung menerapkan Kota Pendidikan Inklusif, yaitu mengharuskan semua sekolah yang berada di Kota Bandung menerima anak berkebutuhan khusus (ABK). Selain itu, pada tahun yang sama diketahui juga bahwa PPDB di Kota Bandung dilaksanakan dengan sistem zonasi atau yang lebih dikenal dengan rayonisasi, yaitu sekolah harus mendahulukan menerima siswa yang bertempat tinggal satu wilayah dengan sekolah tersebut sesuai dengan tempat tinggal siswa tersebut yang diakui secara hukum tertera pada kartu keluarganya. Disamping beberapa perubahan sistem yang dibuat oleh Pemerintah Kota Bandung sendiri, pembentukan sistem pendidikan di Kota Bandung harus tetap mengacu pada sistem pendidikan yang diatur langsung oleh pemerintahan pusat. Berdasarkan catatan dari Kementrian Pendidikan dan Kebudayaan, perubahan kurikulum pelaksanaan pendidikan yang tercatat pada tahun 2016 telah mengalami 3 kali revisi, setelah sebelumnya mengalami 11 kali perubahan sejak tahun 1947 hingga 2015.

Beberapa perubahan sistem pendidikan di Kota Bandung menyebabkan guru harus mampu menghadapi siswa dengan kemampuan dan kebutuhan akan perhatian yang lebih heterogen dibandingkan sebelumnya, yang mana biasanya guru mengajar siswa dengan kemampuan akademik yang setara di dalam satu kelas. Hal tersebut tentu mengharuskan guru dapat menyesuaikan diri dengan memperluas wawasan serta kerampilan dalam mengajar siswa yang heterogen di dalam kelas. Terlebih misi tingkatkan kualitas pendidikan Kota Bandung difokuskan pada tingkat SMP, dimana siswa SMP berada pada usia remaja yang merupakan masa peralihan dari usia anakanak ke usia dewasa yang tentu pada usia 
ini mereka membutuhkan perhatian lebih dan adanya sosok role model bagi pembentukan jati dirinya. Dibutuhkannya role model pada usia remaja ini menjadi pembeda antara guru SMP dengan guru pada tingkat sekolah lainnya.

Dalam hal ini jelas bahwa tuntutan guru di sekolah bukan hanya mengajar secara akademik, tetapi juga moral. Selain itu, mereka harus cepat beradaptasi atas perubahan-perubahan sistem pendidikan yang terjadi dengan cepat dan terusmenerus. Melalui hasil wawancara yang dilakukan pada 10 guru SMP Negeri di Kota Bandung, diketahui bahwa sebanyak 90\% dari mereka mengakui bahwa tuntutan kerja mereka sebagai guru SMPN di Kota Bandung terus bertambah. Selain itu, diakui oleh $100 \%$ dari guru tersebut bahwa mereka membutuhkan dorongan dari pihak sekolah dan pemerintah terkait untuk membantu mereka memperluas wawasan sebagai upaya mempermudah adaptasi mereka terhadap perubahan-perubahan sistem pendidikan tersebut. Hal tersebut diakui oleh sebanyak $70 \%$ dari mereka bahwa mereka membutuhkan usaha lebih dalam beradaptasi pada perubahan-perubahan sistem pendidikan.

Sebagai upaya beradaptasi pada perubahan sistem pendidikan tersebut, guru juga tentu membutuhkan dukungan dari atasannya, yaitu kepala sekolah dan pemerintah serta dukungan dari rekan-rekan sesama guru. Dari wawancara tersebut diatas, diketahui bahwa terdapat $70 \%$ responden yang merasa bahwa mereka telah mendapat dukungan tersebut. Sementara itu, 30\% lagi tidak merasakan dukungan tersebut karena mereka merasa beberapa rekan guru tidak senang ikut terlibat dalam kegiatan-kegiatan yang berupaya mengembangkan diri mereka. Menanggapi sistem pendidikan yang diterapkan di Bandung, terdapat $40 \%$ responden yang mengeluh dengan sistem rayonisasi dalam PPDB Bandung. Mereka mengaku sistem tersebut menuntut mereka harus mendapati siswa dengan karakter yang heterogen dalam kelas. Selain itu dengan diterapkannya sekolah inklusif di Bandung, terdapat $30 \%$ responden mengaku bahwa mereka kesulitan dalam menghadapi siswa berkebutuhan khusus karena mereka merasa butuh adanya pendampingan dari guru yang memang biasa menghadapi ABK. Kesulitan yang dihadapi mereka tersebut diakui membuat diri mereka terkadang kurang bersemangat ketika menghadapi beberapa siswa yang berbeda-beda kemampuannya dalam satu kelas. Sebanyak 20\% dari responden juga pernah merasa tidak dihargai di dalam kelas sebagai guru karena tidak diperhatikan oleh beberapa siswa.

Selain itu dengan pekerjaan sebagai guru $80 \%$ responden mengakui bahwa pekerjaan sebagai guru tidak memberi mereka kesempatan untuk meningkatkan kelas mereka lebih dari sekedar guru, sedangkan $20 \%$ lagi merasa mendapatkan kesempatan karena mereka diberikan tanggung jawab lebih sebagai wakil kepala sekolah, kepala sekolah, dan penanggung jawab pada beberapa bidang tertentu. Dengan pekerjaannya sebagai guru juga, $80 \%$ responden merasa pekerjaan mereka sebagai pekerjaan yang terpuji. Walaupun upah sebagai guru dianggap responden tidak seberapa, namun $70 \%$ responden merasa cukup dengan upah yang didapatkannya, sedangkan $30 \%$ mengaku kurang cukup dengan upah yang diberikan karena terkadang beberapa pihak terlambat memberikan upah dan tunjangan lainnya. Namun dengan hal-hal tersebut, $70 \%$ responden merasa bahwa mereka memiliki gambaran masa depan seperti yang diharapaknnya dengan profesinya sebagai guru.

Berdasarkan hasil wawancara tersebut diketahui kondisi sebenar-benarnya yang dialami guru SMP Negeri Kota Bandung adalah mereka merasa bahwa tuntutan bekerja sebagai guru terus bertambah selain tuntutan sebagai guru yang memang sudah dikerjakannya. Bertambahnya tuntutan tersebut menyebabkan mereka harus terus berusaha memperluas wawasan dan kemampuan agar dapat dengan mudah dan cepat beradaptasi 
pada perubahan tersebut. Apalagi dengan diberlakukannya perolehan pendidikan secara merata di Kota Bandung menyebabkan guru harus dapat mengajar siswa dengan kemampuan yang sangat heterogen di dalam satu kelas yang sama. Akibat mengajar siswa yang heterogen kemampuannya dalam satu kelas, guru merasa hal tersebut menguras usahanya dalam menyampaikan materi pelajaran walaupun terkadang mereka merasa tidak dihargai di dalam kelas tersebut. Guru harus menjaga motivasi mereka bekerja sebagai guru di sekolah yang tentu hal tersebut sudah seharusnya didukung dengan kesempatan belajar yang cukup, kesempatan mendapatkan promosi, mendapatkan upah yang cukup, dukungan dari kepala sekolah dan pihak terkait, pujian dari lingkungan sekitar, dan masa depan yang terjamin. Namun dalam hal ini, masih terdapat sebagian guru yang merasa belum mendapatkan beberapa dari dukungan tersebut. Dengan demikian, didapatkan pertanyaan yang diajukan dalam penelitian ini, yaitu:

1. Bagaimana gambaran umum teacher learning climate pada guru SMPN di Kota Bandung?

2. Bagaimana gambaran umum teacher job satisfaction pada guru SMPN di Kota Bandung?

3. Bagaimana hubungan antara teacher learning climate dan teacher job satisfaction pada guru SMPN di Kota Bandung?

\section{METODE PENELITIAN}

Rancangan dari penelitian ini menggunakan pendekatan kuantitatif noneksperimental, yaitu penelitian yang bertujuan untuk mendapatkan deskripsi atau gambaran yang akurat dari suatu situasi atau fenomena. Rancangan penelitian ini disebut rancangan kuantitatif karena teknik pengambilan datanya berupa angka untuk menjawab pertanyaan penelitian. Metode yang digunakan dalam penelitian ini adalah metode korelasional yang mengukur dua variabel kemudian menentukan derajat hubungan dari kedua variabel tersebut. Sedangkan pengambilan data dari penelitian ini dilakukan menggunakan dua kuesioner yang mengukur teacher learning climate dan teacher job satisfaction.

Alat ukur teacher learning climate mengacu pada alat ukur dari (Yang et al., 2004) yang mengukur persepsi guru atas upaya pembelajaran guru di sekolah dalam bentuk kuesioner yang berjumlah 18 item pernyataan dengan 6 skala alternatif jawaban dari skala 1 (sangat jarang) sampai skala 6 (sangat sering) dengan nilai reliabilitas cronbach alpha sebesar 0.890 . Sedangkan alat ukur job satisfaction mengacu pada alat ukur dari (Lester, 1987) yang mengukur tingkat kepuasan kerja dalam bentuk kuesioner yang berjumlah 31 item pernyataan dengan 4 skala alternatif jawaban dari skala 1 (sangat tidak sesuai) sampai skala 4 (sangat sesuai) dengan nilai reliabilitas cronbach alpha sebesar 0.864 .

Subjek dalam penelitian ini adalah guru yang aktif mengajar pada periode ajar 2017/2018 di SMP Negeri Kota Bandung. Populasi guru yang terdaftar aktif mengajar di SMPN Kota Bandung periode 2017/2018 adalah sebanyak 5400 guru yang tersebar pada 54 sekolah. Sedangkan dalam penelitian ini digunakan teknik cluster random sampling, karena karakterisitk subjek bersifat homogen, yaitu guru merupakan Pegawai Negeri Sipil (PNS) yang terdaftar sebagai guru di SMP Negeri Kota Bandung. Kelompok subjek dalam penelitian ini ditentukan berdasarkan jumlah SMPN yang ada di Kota Bandung, yaitu sebesar $10 \%$ dari 54 sekolah, sehingga dapat ditentukan 6 SMPN terpilih di Kota Bandung yang didapatkan dengan cara mengacak daftar 54 SMPN tersebut. Dalam penelitian ini sendiri jumlah responden yang berpartisipasi adalah 109 guru yang aktif mengajar dan tersebar pada enam SMPN Kota Bandung, yaitu SMPN 1, SMPN 2, SMPN 5, SMPN 9, SMPN 26, dan SMPN 50 Bandung.

ANALISIS \& HASIL 


\section{Gambaran Umum Teacher Learning Climate}

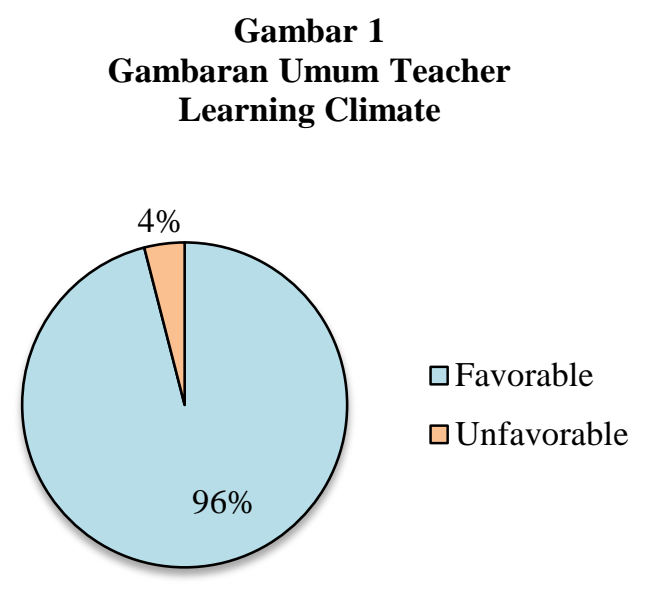

Dalam hal ini, yang dimaksud dengan kategori favorable pada TLC adalah persepsi yang positif (baik) yang dimiliki guru pada iklim belajar yang terbangun di sekolah. Sedangkan kategori unfavorable adalah persepsi yang negatif (buruk) mengenai iklim belajar guru di sekolah. Berdasarkan hasil olah data penelitian, maka didapatkan sebanyak 96\% (105 responden) memiliki persepsi favorable terhadap iklim belajar guru pada sekolah tempatnya mengajar dan 4\% (4 responden) sisanya memiliki persepsi buruk terhadap iklim belajar guru pada sekolah tempatnya mengajar. Hal ini berarti mayoritas guru SMPN Kota Bandung memberikan penilaian bahwa iklim belajar di SMPN Kota Bandung sudah cukup baik ditandai dengan upaya-upaya yang dilakukan sekolah dalam rangka mendukung pembelajaran guru. Namun juga dapat diketahui bahwa masih terdapat sedikit responden yang menilai buruk iklim belajar guru yang ada pada sekolahnya. Selain itu, berdasarkan diagram tersebut dapat diartikan juga bahwa secara umum guru SMP Negeri Kota Bandung memiliki persepsi yang baik terhadap iklim belajar guru yang ada di sekolah. Artinya, teacher learning climate pada SMP Negeri Kota Bandung sudah baik dan sesuai dengan iklim belajar yang dibutuhkan oleh guru untuk meningkatkan kemampuan mereka agar dapat menyesuaikan pada perubahanperubahan sistem pendidikan yang ada.

\section{Gambaran Umum Job Satisfaction}

Gambar 2

Gambaran Umum Job Satisfaction Guru

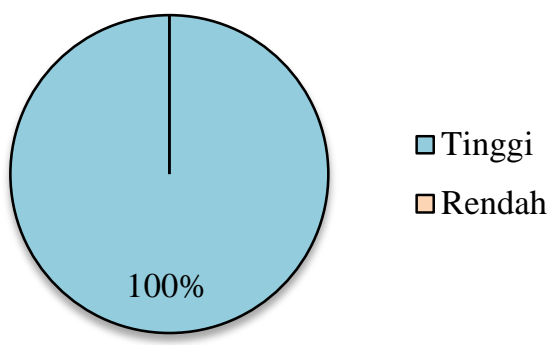

Selain itu, tingkat kepuasan kerja guru SMPN di Kota Bandung diketahui bahwa sebanyak 100\% (109 responden) tingkat kepuasan kerjanya masuk pada kategori tinggi, yang berarti bahwa secara umum seluruh guru SMP Negeri yang menjadi responden pada penelitian ini puas terhadap pekerjaannya sebagai guru. Tingginya tingkat kepuasan kerja guru di SMP Negeri Kota Bandug dapat menggambarkan bahwa guru SMP Negeri Kota Bandung memiliki sikap yang positif pada pekerjaannya sebagai guru di SMP Negeri Kota Bandung, sehingga mereka dapat menikmati pekerjaannya dengan tenang dan nyaman di SMP Negeri Kota Bandung. Selain itu, tingginya tingkat kepuasan kerja tersebut juga menggambarkan bahwa SMP Negeri Kota Bandung dapat mendorong dan memenuhi kebutuhan guru untuk memiliki sikap positif atas pekerjaannya melalui faktor-faktor ekstrinsik dan instrinsik dari pekerjaan guru itu sendiri sehingga guru dapat mencapai kepuasan kerja yang tinggi.

Uji Korelasi Teacher Learning Climate dengan Job Satisfaction

Tabel 1 Uji Korelasi Teacher Learning Climate dengan Job Satisfaction

Job Keterangan




\begin{tabular}{llll}
\hline & & Satisfaction & \\
\hline $\begin{array}{l}\text { Teacher } \\
\text { Learning } \\
\text { Climate }\end{array}$ & Sig. & 0.000 & Tolak Ho \\
\hline & & & \\
& $\begin{array}{l}\text { Correlation } \\
\text { Coefficient }\end{array}$ & $0.677^{* *}$ & \\
\hline
\end{tabular}

Dalam penelitian ini, uji korelasi dilakukan dengan menggunakan uji korelasi Spearman. Berdasarkan hasil perhitungan software IBM SPSS for Macintosh version 21 didapatkan bahwa nilai signifikansi, yaitu 0,000 berada di bawah 0,05 ( $\mathrm{p}<$ 0,05), sehingga Ho ditolak dan H1 diterima yang berarti bahwa terdapat hubungan yang signifikan antara teacher learning climate dan job satisfaction pada guru SMP Negeri Kota Bandung.

Selain itu didapatkan hasil dalam penelitian ini bahwa besarnya korelasi kedua variabel sebesar 0,677 yang berarti masuk dalam kategori korelasi yang kuat (Guilford, 1956). Artinya, teacher learning climate dan job satisfaction pada guru SMP Negeri Kota Bandung memiliki hubungan yang kuat. Nilai korelasi kedua variabel yang memiliki nilai positif menunjukkan bahwa hubungan yang dimiliki bersifat searah, yaitu semakin baik persepsi iklim belajar guru maka akan semakin baik kepuasan kerjanya. Begitu juga sebaliknya, semakin buruk persepsi iklim belajar guru di sekolah, maka akan semakin rendah kepuasan kerjanya. Secara keseluruhan hal ini berarti bahwa terdapat hubungan yang kuat antara teacher learning climate dan job satisfaction pada guru SMP Negeri Kota Bandung, signifikan, dan hubungannya bersifat searah.

Dalam hal ini, besarnya kontribusi variabel teacher learning climate terhadap job satisfaction pada guru dapat dihitung melalui besarnya nilai korelasi yang sudah didapatkan pada tabel 1. Besarnya nilai kontribusi bisa didapatkan dengan menghitung nilai koefisien determinasi $\left(K_{D}\right)$, yaitu dengan menguadratkan nilai korelasi (r). Melalui nilai korelasi $\mathrm{r}=0.677$ jika dikuadratkan menjad $i r^{2}=0.458$, artinya $45.8 \%$ dari varians teacher learning climate SMP Negeri Kota Bandungdapat dijelaskan melalui kepuasan kerja gurunya, sedangkan $54,2 \%$ sisanya merupakan faktor lainnya.

\section{DISKUSI}

Guru merupakan salah satu sumber daya utama berjalannya kegiatan belajar mengajar di sekolah. Oleh karena itu, memperhatikan kebutuhan guru merupakan hal yang penting untuk diperhatikan, terutama kebutuhannya untuk berkembang mengikuti tuntutan perubahan sistem pendidikan dan perubahan zaman disekitarnya. Hal tersebut mengakibatkan dibutuhkannya iklim lingkungan sekolah yang mendorong dan mendukung guru untuk berusaha memperluas pengetahuan dan kemampuannnya agar dapat menyesuaikan pada perubahan-perubahan tersebut.

Berdasarkan hasil penelitian yang telah dilakukan, didapatkan bahwa 96\% dari keseluruhan responden masuk dalam kategori favorable. Dimana hal ini menggambarkan bahwa mayoritas guru SMP Negeri Bandung mempersepsikan bahwa lingkungan sekolahnya memiliki iklim belajar guru yang baik. Persepsi yang baik pada iklim belajar guru di sekolah tersebut memberi maksud bahwa sekolah beserta unsur-unsur terkait didalamnya sudah cukup berupaya untuk memberi guru dorongan dalam berbagai macam bentuk. Upaya sekolah yang dirasa guru paling terpenuhi untuk mendukung pembelajaran guru adalah collaboration and team learning. Artinya, guru merasa dirinya akan lebih dapat mengupayakan pembelajaran melalui tersedianya fasilitas sekolah yang mendukung mereka dapat bertukar pikiran dan mengakses berbagai macam pola pikir baru. Dimana fasilitas tersebut biasanya berbentuk forum-forum diskusi kelompok guru di sekolah maupun di luar sekolah. Seperti didapatkan dari data hasil wawancara pada penelitian ini juga bahwa mereka mengakui sekolah telah memberi kesempatan mereka belajar dalam bentuk mengikuti seminar-seminar pelatihan dan pendidikan, dan juga forum MGMP yang diadakan rutin dalam kurun waktu tertentu. 
Pada penelitian ini, didapatkan gambaran secara umum bahwa guru SMP Negeri Kota Bandung telah mencapai kepuasan kerja, yaitu sebanyak $100 \%$ dari responden secara masuk dalam kategori tinggi. Artinya, secara umum guru SMP Negeri Kota Bandung memiliki kepuasan kerja yang tinggi.

Dalam penelitian ini, kepuasan kerja yang paling tinggi ditunjukkan pada kepuasan guru SMP Negeri Kota Bandung terhadap responsibility. Artinya, guru SMP Negeri Kota Bandung memiliki sikap yang positif terhadap tanggung jawab atas pekerjaannya sebagai guru dengan tanggung jawab guru paling besar terhadap tindakannya sendiri di sekolah. Selain itu, guru juga merasa bertanggung jawab atas keberhasilan siswanya dan mematuhi kebijakan sekolah. Secara keseluruhan berdasarkan analisis pada penelitian ini kepuasan kerja guru SMP Negeri Kota Bandung yang tinggi ditunjukkan dengan adanya sikap positif guru terhadap dekatnya hubungan yang dibangun oleh guru terhadap pihak-pihak yang berhubungan dengan sekolah, seperti siswa atau walinya, kepala sekolah, rekan kerja, dan dengan sekolah itu sendiri sehingga. Kehangatan tersebut kemudian dapat mendukung lingkungan kerja guru yang nyaman, sehingga guru dapat menikmati pekerjaannya sebagai guru dan menggunakan berbagai keterampilan yang dimiliki saat bekerja.

Hubungan teacher learning climate dengan job satisfaction pada guru ditunjukkan dengan besarnya koefisien determinasi dari tersebut, yaitu sebesar 0,458 yang berarti bahwa 45,8\% varians dari job satisfaction dapat dijelaskan berdasarkan iklim belajar guru di sekolah, sedangkan 54,2\% sisanya dipengaruhi faktor lain, seperti faktor antesenden dari kepuasan kerja itu sendiri misalnya status atau jabatan dari individu yang dapat berakibat juga pada hubungannya dengan kepala sekolah, rekan kerja, dan kondisi pekerjaannya dimana individu dengan jabatan yang lebih tinggi mungkin akan memiliki fasilitas yang lebih lengkap dan hubungan yang lebih banyak dan dekat dengan rekan kerja lain sehingga hal tersebut juga mempengaruhi tingkat kepuasan kerjanya di sekolah. Selain itu, karakteristik dari diri guru itu sendiri juga mungkin menjadi faktor lain yang dapat mempengaruhi kepuasan kerja guru.

$$
\text { Upaya mewujudkan hasil }
$$
pembelajaran siswa yang baik, maka kita perlu membuka kesempatan belajar yang lebih luas bagi guru. Dicanangkannya 6 misi tingkatkan kualitas pendidikan di Indonesia yang salah satunya memang ditujukan pada sekolah menengah pertama (SMP) memberi tuntutan tersendiri bagi guru. Apalagi, seperti telah didapatkan dari data awal bahwa guru SMP merasa dirinya memiliki tugas lebih dari sekedar guru pada tingkatan lainnya, dimana mereka harus menjadi role model yang baik bagi siswa yang berada pada usia remaja. Tuntutantuntutan pada guru yang terus bertambah dan juga berkembang mengikuti perkembangan zaman, mengharuskan guru mendapatkan kebebasan memperluas wawasan dan keterampilannya dalam mengajar. Oleh karena itu iklim belajar guru menjadi sangat penting di sekolah.

\section{SIMPULAN}

Berdasarkan hasil dan pembahasan yang telah dipaparkan dalam penelitian ini mengenai hubungan antara teacher learning climate dengan job satisfaction pada Guru SMP Negeri Kota Bandung, dapat ditarik beberapa simpulan sebagai berikut:

1. Teacher learning climate pada SMP Negeri Kota Bandung secara keseluruhan masuk dalam kategori favorable. Artinya iklim belajar guru di SMP Negeri Kota Bandung sudah dipandang baik, ditandai dengan mayoritas persepsi guru yang baik terhadap segala bentuk dukungan pembelajaran guru oleh lingkungannya. Persepsi tersebut didapatkan dari persepsi guru terhadap aspek-aspek teacher 
learning climate yang secara keseluruhan masuk pada kategori favorable, yaitu persepsi guru yang memandanga baik iklim belajar guru di sekolah.

2. Tingkat job satisfaction pada guru SMP Negeri Kota Bandung masuk pada kategori tinggi. Hal tersebut menunjukkan bahwa guru merasakan kepuasan dalam bekerja sebagai guru di SMP Negeri Kota Bandung. Job satisfaction guru yang terbagi dalam sembilan aspek secara keseluruhan masuk dalam kategori tinggi. Namun, satu dari sembilan aspek tersebut masuk dalam kategori rendah, yaitu advancement. Rendahnya tingkat job satisfaction pada aspek advancement tersebut menunjukkan bahwa guru SMP Negeri Kota Bandung merasa tidak puas atas tidak luasnya kesempatan promosi yang didapatkan atas kerja mereka sebagai guru.

3. Terdapat hubungan positif antara teacher learning climate dengan job satisfaction pada guru dan masuk dalam kategori korelasi yang erat yang saling berhubungan. Hal ini menunjukkan apabila SMP Negeri Kota Bandung dapat memberikan kesempatan pembelajaran guru yang luas, maka tingkat kepuasan kerja guru akan tinggi. Sebaliknya, semakin sempit SMP Negeri Kota Bandung memberi kesempatan pembelajaran guru maka hal tersebut memungkinkan tingkat job satisfaction guru yang rendah.

\section{SARAN}

Saran yang dapat diajukan berdasarkan penelitian yang telah dilakukan bagi guru adalah dengan diketahuinya bahwa iklim belajar guru yang baik dapat meningkatkan kepuasan kerja. Maka, kesempatan pembelajaran yang telah disediakan oleh pihak sekolah dan pemerintah penting untuk diikuti sebagai wadah memperluas wawasan dan keterampilan yang akan mempermudah tercapainya kepuasan kerja di sekolah. Selain itu, juga terdapat manfaat bagi pihak sekolah dengan diketahuinya korelasi antara teacher learning climate dengan jobsatisfaction, maka sekolah dapat memaksimalkan upaya yang mendukung pembelajaran guru di sekolah juga sebagai salah satu upaya meningkatkan tingkat kepuasan kerja guru. Disamping itu bagi pihak pemerintah yang mengatur sistem pendidikan secara keseluruhan juga dapat mamanfaatkan hasil penelitian ini sebagai acuan membentuk peraturan-peraturan baru pada sistem pendidikan yang juga mendukung pembelajaran guru sebagai upaya meningkatkan kualitas tenaga kependidikan, yaitu guru.

\section{DAFTAR PUSTAKA}

Ayele, D. (2014). Teachers' job satisfaction and commitment in general secondar y schools of hadiya zone in southern nation nationality and people of regional state (Thesis) . Jimma University, Ethiophia. Diakses dari https://opendocs.ids.ac.uk/opendocs/handl e/123456789/5340

Nurdiansyah, A.S. (2011). Profesionalisme guru dan tantangan kedepan dalam peningkatan mutu pendidikan pada era global. Diakses dari http://ap.fip.um.ac.id/wpcontent/uploads/2016/03/13-Aziz-ShofiNurdiansyah.pdf.

Mirzamani,M., Khorshidi, A., Moosavipanah, S.M. (2012). A review of the relationship between employment status, educational degree, occupational background and organizational climate with job satisfaction among teachers from training and education organization (TEO) at Baharestan Town, Tehran, Journal of Educational and Management Studies, 2(2), 48-54.

Erdem, M., İlğan, A., \& Uçar, H. İ. (2014). Relationship between learning organization and job satisfaction of 
primary school teachers. International Online Journal of Educational Sciences, 6(1), 8-20.

https://doi.org/10.15345/iojes.2014.01.002

Pramesti, S.I (2018). Identification of accreditation assessment system in non formal education. Prosiding Seminar Nasional Pendidikan (pp.190-200). Universitas Sarjanawiyata, Yogyakarta.

Lester, P. E. (1987). Development and factor analysis of the teacher job satisfaction questionnaire (TJSQ). Educational and Psychological Measurement, 47(1), 223233.https://doi.org/10.1177/00131644874 71031

Mooradian, T., Renzl, B., \& Matzler, K. (2006). Who trusts? Personality, trust and knowledge sharing. Management Learning, 37(4), 523-540. https://doi.org/10.1177/135050760607342 4

Renkl, A., \& Atkinson, R. K. (2007). Interactive learning environments: Contemporary issues and trends. An introduction to the special issue. Educational Psychology Review, 19(3), 235-238. https://doi.org/10.1007/s10648007-9052-5

Von Der Embse, N. P., Sandilos, L. E., Pendergast, L., \& Mankin, A. (2016). A mediation analysis of teacher stress, selfefficacy, and job satisfaction. Learning and Individual Differences, 50, 308-317.

Shoshani, A., \& Eldor, L. (2016). The informal learning of teachers: Learning climate, job satisfaction and teachers' and students' motivation and well-being. International Journal of Educational Research, 79, 5263.

https://doi.org/10.1016/j.ijer.2016.06.007

Sosiawan, E. A. (2008). Tantangan dan hambatan dalam implementasi EGovernment di Indonesia. Prosiding Seminar Nasional Informatika (pp. 99108). UPN Veteran, Yogyakarta.

Yang, B., Watkins, K. E., \& Marsick, V. J. (2004). The construct of the learning organization: Dimensions, measurement, and validation. Human Resource

Development Quarterly, 15(1), 31-55.

https://doi.org/10.1002/hrdq.1086 